\title{
AUDIO VISUAL TEACHING MATERIALS BASED ON FLASH TO TRAIN STUDENTS SKILL TO CREATE MIND MAPPING IN SIMPLE HARMONIC MOTION
}

\author{
Reni Puspitasaria), Yetti Supriyati ${ }^{\text {b) }}$, Dwi Susantic) \\ Physics Education, Faculty of Mathematics and Natural Science, State University of Jakarta Jl. Rawamangun \\ Muka No. 1. Jakarta Timur, 13220 Indonesia
}

Email:a)puspitareni95@gmail.com, ${ }^{\text {b) }}$ yetti.supriyati@unj.ac.id, ${ }^{\text {c) } d w i . s u s a n t i @ g m a i l . c o m ~}$

\begin{abstract}
Abstrak
This study aims to develop audio-visual teaching materials based on flash that can make students rewrite every recovered material in mind mapping on simple harmonic motion materials. Teaching materials development is based on the basic revision competence of the 2013 curriculum in x class. This study uses the method of research and development (RND) with an ADDIE development model. This ADDIE development models have five stages, the analytic stages (Analytic), the development stages (Development), the implementation (Implementation), and the evaluating stage (Evaluation). The product produced in the form of flash-based audio-visual teaching material can be used to support learning activities by teachers and independent teaching materials to practice skills in making mind mapping quickly. Assessments of the product are made by materials experts, media experts, and learning professionals. Product trials are conducted on high school physics teachers and high school students.
\end{abstract}

\section{PENDAHULUAN}

In the learning process, teaching materials are needed to make effective interactions between teachers and students, the lack of teaching materials used sometimes becomes an obstacle in the learning process so that the information that should be conveyed in the learning process is less than optimal. Besides the lack of facilities and infrastructure becomes an obstacle in the delivery of material in the learning process. Therefore, we need a teaching material that can increase student motivation in learning so that they are more interested in learning physics. Teaching materials are all materials (both information, tools, and texts) that are arranged systematically, which displays a complete figure of the competencies that will be mastered by students and used in the learning process with the aim of planning and studying learning implementation. For example, textbooks, modules, worksheets, visual teaching materials, audiovisual teaching materials, interactive teaching materials, and others [1].

Audiovisual teaching material presents audio and visuals containing good learning messages that contain concepts, principles, procedures, theories, applications to help to understand the learning material [2]. Audiovisual teaching materials are very supportive of learning physics especially for materials that use a lot of depictions such as simple harmonic motion kinematics. Audiovisual teaching materials can describe a process appropriately and can be seen repeatedly and can encourage and motivate students to keep seeing it. In general, the basic concepts of physics become clearer when applied to everyday phenomena. This adds to the pleasure of students to learn physics. The use 
of audio visual teaching materials in the process of learning physics, can help students to observe natural phenomena [3].

In learning physics, one of the usual student activities is taking notes. But from the majority of students, there are not many students who have interesting notes so physics is not interesting because it only records questions and formulas. Interesting physics learning requires activities that are student-centered orientation and can train students to be creative and active during the learning process. Therefore mind maps are an effective, creative, interesting, and easy way to use as a medium to repeat physics lessons easily. According to Buzan, mind maps are the easiest way to enter information into the brain and to retrieve information from the brain again [4].

Students' ability to think can also be trained through assignments to make mind mapping. Mind mapping is applied to inculcate concepts and improve understanding of physical concepts so that students are easier to remember the material that has been taught, with mind mapping students are able to reconstruct the information that has been obtained. Silaban's research shows that the high creativity of students with mind mapping is due to mind mapping being able to connect new and unique ideas with existing ideas. Giving rise to actions taken by students. Through the use of colors and interesting symbols that will create a creative product produced by students in learning activities. Students will also be able to remember material longer with the help of mind maps. [5]

Therefore, the authors are interested in researching the development of flash-based audiovisual teaching materials to train students' skills in making mind mapping on simple harmonic motion kinematics material.

\section{METODOLOGI}

This research uses the Research and Development $(\mathrm{RnD})$ method. The development model used is the ADDIE model. ADDIE model is one of the systematic learning designs. "ADDIE" itself stands for Analyze, Design, Development, Implementation, Evaluation. The ADDIE model is considered dynamic because at each stage it can be evaluated so that researchers can revise errors or deficiencies in each stage of development [6]. Several teaching material developments also use the ADDIE RnD model, such as The Development of Web-based Instructional Media for Teaching Wave Physics on Android Mobile [7] and The Development of Blended Learning Model [8]. These stages can be seen from the following chart:

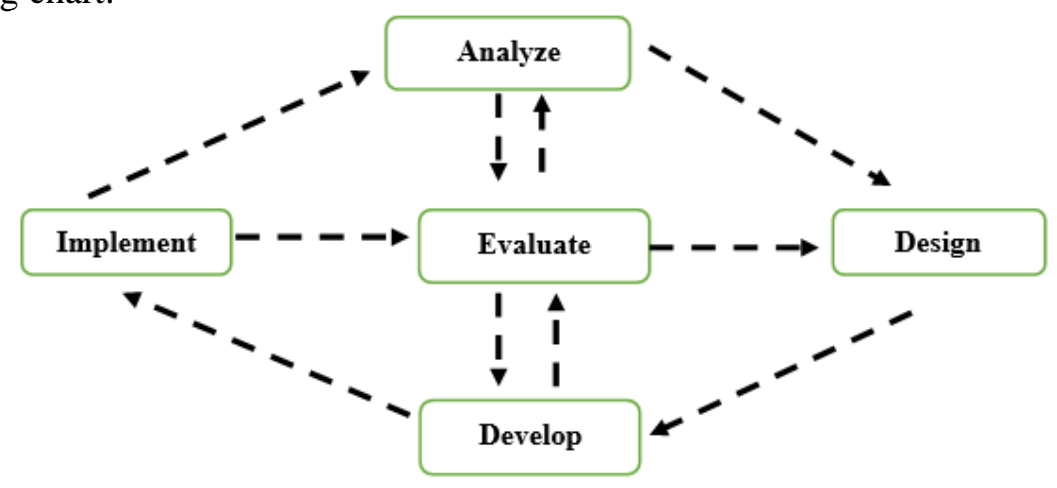

FIGURE 1. Stage of ADDIE Model Development

\section{Analyze}

The analysis phase is a defining process. The analysis phase is the process of defining what participants will learn. So to find out or determine what should be learned, we must do several activities, including conducting a needs assessment. At this stage, a literature study is also conducted which aims to find out that audio-visual teaching material to train students' ability to make mind mapping needs to be developed. 


\section{Design}

This stage is also known as making a design. Because in the analysis phase it has been seen that flash-based audio- visual teaching materials can train the ability to make mind mapping needs to be developed, so this stage is carried out the design of teaching materials. Researchers design learning product designs in the form of storyboards that make story ideas planning, visualization, narration, and the duration of the video to be developed.

\section{Development}

Product development begins with collecting materials that have been determined in the storyboard. Preparation of teaching materials in the order of material that contains pictures and videos Audiovisual teaching materials products are prepared using Adobe Flash software by the storyboard. In this preparation, all components of teaching materials will be combined An important step in the development phase is a trial before it is implemented. This trial phase is indeed part of one ADDIE step, which is evaluation. More precisely formative evaluation, because the results are used to improve the learning system developed.

\section{Implementation}

This stage is a concrete step to apply the teaching material that we are making. This stage is done for students of class X MIPA. At this stage, the researcher himself who will teach in this stage is not a physics teacher in the school.

\section{Evaluation}

The evaluation phase is carried out at the end of each existing stage. The evaluation phase aims to find what information can make teaching materials better and what makes teaching materials less tidy to be used as revision purposes. The validation instrument used was a Likert scale questionnaire with respondents from material experts, media experts, teachers, and class X students. In addition, the data analysis technique was used using a gain test to measure whether or not the ability of students was based on the results of the pretest and posttest.

\section{RESULT AND DISCUSSION}

The product produced from this research is flash-based audio-visual teaching material as one of the sources of learning simple harmonic motion material in high schools in accordance with the basic competencies in the revised 2013 Curriculum. The product is created using the Adobe Flash application.

In the initial stages, literature studies and field studies are conducted. A literature study is carried out by looking for reference material kinematics straight motion and field studies are doing observations in the field by exploring information on problems and identifying problems. At the development stage carried out. Collection of draft material, script, and video storyboard according to the syllabus. The compilation process uses Adobe Flash. the results of teaching materials in the form of flash

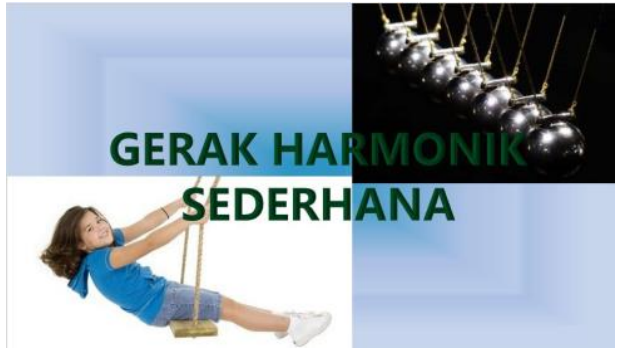

FIGURE 2. Opening

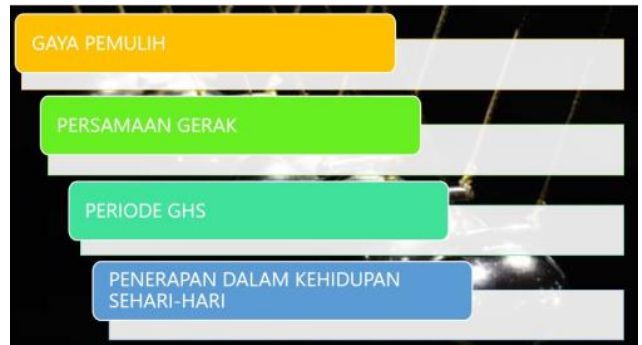

FIGURE 2. Material

Seminar Nasional Fisika 2020

Program Studi Fisika dan Pendidikan Fisika, Fakultas MIPA, Universitas Negeri Jakarta 
Besides being used for teaching materials, that teacher can also use flash to make the Test Tool by Rasch Model for Physics National Examination [9]. In motion material and harmonic vibrations in high school physics, it also discusses kinematics. To train other students skills, such as science process skills, the teacher can teach students to make graphs [10,11]. Students can do this by utilizing motion videos, which are then analyzed using tracker software [12].

\section{CONCLUSION}

This audiovisual teaching material is designed to train students' skills in making mind mapping by processing every information obtained from flash-based audiovisual teaching material. This audiovisual teaching material can also help the teacher visualize simple harmonic motion materialGambar dan tabel.

\section{REFERENSI}

[1] D. Griffiths, "Pengantar Partikel Dasar," Wiley-VCH, 2008.

[2] T. Buzan, "Buku Pintar Mind Map," Jakarta: Gramedia, 2007.

[3] R. Silaban, "Pengaruh media mind mapping terhadap kreativitas dan hasil belajar kimia siswa SMA pada pembelajaran menggunakan advance organizer," 2012.

[4] I. M. Tegeh and I. M. Kirna, "Metode Penelitian Pengembangan Pendidikan," Singaraja: Universitas Pendidikan Ganesha, 2010.

[5] E. Suherman, Winaputra and Udin, "Materi Pokok Strategi Belajar Mengajar Matematika," Jakarta: Debdikbud, 1993.

[6] A. Prastowo, "Panduan Kreatif Membuat Bahan Ajar Inovatif: Menciptakan Metode Pembelajaran yang Menarik dan Menyenangkan," Yogyakarta: DIVA Press, 2012.

[7] B. R. Simanjuntak, D. Desnita, and E. Budi, "The Development of Web-based Instructional Media for Teaching Wave Physics on Android Mobile", JPPPF (Jurnal Penelitian dan Pengembangan Pendidikan Fisika), vol. 4, no. 1, pp. 1 - 10, Jun. 2018.

[8] Y. R. Denny, I. S. Utami, S. Rohanah, and D. Muliyati, "The Development of Blended Learning Model using Edmodo to Train Student Critical Thinking Skills on ImpulseMomentum Topic", JPPPF (Jurnal Penelitian dan Pengembangan Pendidikan Fisika), vol. 6, no. 1, pp. 113 - 120, Jun. 2020.

[9] Y. Supriyati, R. Raihanati, and W. Nilawati, "The Development of Horizontal Anchor Items Test Tool by Rasch Model for Physics National Examination using Macromedia Flash", JPPPF (Jurnal Penelitian dan Pengembangan Pendidikan Fisika), vol. 6, no. 1, pp. 37 - 50, Jun. 2020.

[10] I. M. Astra and R. S. Wahidah, "Peningkatan Keterampilan Proses Sains Siswa Melalui Model Guided Discovery Learning Kelas XI MIPA pada Materi Suhu dan Kalor", JPPPF (Jurnal Penelitian dan Pengembangan Pendidikan Fisika), vol. 3, no. 2, pp. 181 - 190, Dec. 2017.

[11] A. Malik, E. Kurnia Y, and S. Robiatus S, "Peningkatan Keterampilan Proses Sains Siswa melalui Context Based Learning", JPPPF (Jurnal Penelitian dan Pengembangan Pendidikan Fisika), vol. 2, no. 1, pp. 23 - 30, Jun. 2016.

[12] F. I. Dewi, N. A. Wibowo, D. N. Sudjito, and F. Rondonuwu, "The Design of OneDimensional Motion and Two-Dimensional Motion Learning Media Using Digital Camera and Tracker-Based Air Track", JPPPF (Jurnal Penelitian dan Pengembangan Pendidikan Fisika), vol. 6, no. 1, pp. 65 - 74, Jun. 2020. 